\title{
Spring production of mycosporine-like amino acids and other UV-absorbing compounds in sea ice-associated algae communities in the Canadian Arctic
}

\author{
Ashley Elliott ${ }^{1}$, C. J. Mundy ${ }^{1}$, Michel Gosselin ${ }^{2}$, Michel Poulin ${ }^{3}$, Karley Campbell ${ }^{1}$, \\ Feiyue Wang ${ }^{1, *}$ \\ ${ }^{1}$ Center for Earth Observation Science, Department of Environment and Geography, University of Manitoba, Winnipeg, \\ MB R3T 2N2, Canada \\ ${ }^{2}$ Institut des sciences de la mer de Rimouski, Université du Québec à Rimouski, Rimouski, QC G5L 3A1, Canada \\ ${ }^{3}$ Research and Collections Division, Canadian Museum of Nature, Ottawa, ON K1P 6P4, Canada
}

\begin{abstract}
Marine phytoplankton are known to produce mycosporine-like amino acids (MAAs) for protection against UV radiation. To assess whether the same strategy applies to sea ice-associated communities, MAAs were measured in algal communities associated with surface melt ponds, sea ice (bottom $3 \mathrm{~cm}$ ), sea ice-water interface below melt ponds, and underlying seawater in a coastal bay of the Canadian Arctic Archipelago during the spring melt transition from snowcovered to melt pond-covered sea ice. Six UV-absorbing compounds (UVACs) were detected as the spring melt progressed, 3 of which are identified to be shinorine, palythine, and porphyra-334. A fourth UVAC (U1) is most likely palythene. The molecular identities of the other 2 UVACs, U2 and U3, which have an absorption maximum of 363 and $300 \mathrm{~nm}$, respectively, remain to be structurally elucidated. The highest UVAC nominal concentrations were observed in the $3 \mathrm{~cm}$ bottom ice under thin snow-covered sites just prior to complete snowmelt. Normalization to chlorophyll a content revealed that the greatest contribution to UV absorption from biota was associated with melt ponds that are exposed to the highest light intensity. These results confirm that Arctic sea ice-associated communities are capable of producing photoprotectants and that spatial and temporal variations in MAA and other UVAC synthesis are affected by snow cover and UV radiation exposure.
\end{abstract}

KEY WORDS: Mycosporine-like amino acids - Sea ice community · Ultraviolet radiation · Photoprotection · Arctic Ocean · Algae

\section{INTRODUCTION}

Ultraviolet (UV) radiation $(280-400 \mathrm{~nm})$ causes a reduction in photosynthetically incorporated carbon (Villafañe et al. 2004), although the extent of this photoinhibition is variable among species due to different protective strategies. One such strategy that many algae use to protect against the detrimental effects of UV radiation is the production of mycosporine-like amino acids (MAAs), which are water soluble, UVabsorbing compounds of small molecular weight (Shick \& Dunlap 2002). The precursor for this class of

${ }^{*}$ Corresponding author: feiyue.wang@umanitoba.ca molecules is 4-deoxygadusol (Fig. 1), the biosynthesis of which is presumably through the shikimate or pentose phosphate pathway (Spence et al. 2012). The addition of amino acids, amino alcohols and other amino groups results in the formation of a variety of MAAs, over 20 of which have been structurally elucidated to date (Carreto \& Carignan 2011). A few example MAAs are shown in Fig. 1. These compounds each have a characteristic absorption peak with an absorption maxima $\left(\lambda_{\max }\right)$ between 309 and $362 \mathrm{~nm}$ (Carreto et al. 2005, Carreto \& Carignan 2011, Gao \& GarciaPichel 2011). MAAs may also be involved in other

() The authors 2015. Open Access under Creative Commons by Attribution Licence. Use, distribution and reproduction are unrestricted. Authors and original publication must be credited. 
<smiles>COC1=C(O)CC(O)(CO)CC1=O</smiles>

4-deoxygadusol<smiles>COC1=C(NC(CO)C(=O)O)CC(O)(CO)CC1=NCC(=O)O</smiles>

Shinorine<smiles>COC1=C(N=C(O)CO)CC(O)(CO)CC1=NC(C)C(=O)O</smiles>

Euhalothece-362<smiles>COC1=C(N=C2CC(=N)CC(O)(CO)C2)CCC(=O)O1</smiles>

Palythine<smiles>C/C=C/N=C1CC(O)(CO)CC(=NCC(=O)O)C1OC</smiles>

Palythene<smiles>COC1=C(NC(C(=O)O)C(C)O)CC(O)(CO)CC1=NCC(=O)O</smiles>

Porphyra-334

Fig. 1. Structures of 4-deoxygadusol and a few example mycosporine-like amino acids referred to in this study

cellular functions such as antioxidation (Dunlap \& Yamamoto 1995, Suh et al. 2003), molecular repair (Shick \& Dunlap 2002), and osmotic regulation (Oren 1997). In tropical and temperate oceans experiencing high UV radiation, the ability to synthesize or acquire MAAs appears to be primarily by pelagic dinoflagellates, diatoms, prymnesiophytes, macroalgae (most commonly red algae), and cyanobacteria (Karsten et al. 1998, Sinha et al. 2001, Sommaruga et al. 2009) .

Algal communities in ice-covered polar seas inhabit environments that are characterized by strong gradients in solar radiation, temperature, and salinity. During spring melt, the sea ice surface transitions from cold dry snow cover to melt pond coverage. During this transition the amount of incident photosynthetically active radiation (PAR, 400$700 \mathrm{~nm}$ ) transmitted through sea ice can exponentially increase over just a few weeks from $<1$ to $5-22 \%$ and from $<1$ to $21-67 \%$ under white ice (i.e. drained surface ice above the local water table) and melt ponds, respectively (Ehn et al. 2011, Mundy et al. 2014). This transition coincides with the timing of peak downwelling irradiance resulting in exposure of sea ice and associated communities to high levels of UV radiation and PAR. Further, the effect can be amplified by light scattering at the ice surface and within the sea ice. During the melt transition, sea ice-associated algae living at the surface, within and immediately under the sea ice can potentially exhibit considerable photoprotective strategies including the production of MAAs. However, the occurrence and temporal evolution of MAAs, and their relative importance in UV radiation attenuation in ice-associated communities, remain poorly known. By exposing an Antarctic bottom ice algal community to UV radiation in situ for $15 \mathrm{~d}$, Ryan et al. (2002) detected low concentrations of MAAs and concluded that MAAs may only play a minor role as photoprotectants in sea ice algae. In contrast, relatively high MAA concentrations were measured in the surface layer of landfast ice in the Baltic Sea, upon the melting of snow (Uusikivi et al. 2010), in snow-covered ice and in snow-free ice upon experimental exposure to UV radiation (Piiparinen et al. 2015). The difference between these studies could be due to the exposure of the surface community to greater light intensity in the studies of Uusikivi et al. (2010) and Piiparinen et al. (2015). MAAs were also measured in phytoplankton communities in spring near the ice edge along the Svalbard coast of the Arctic Ocean, though their concentrations were lower than those in open water away from the ice margin (Ha et al. 2012).

Rapid decreases in Arctic sea ice thickness and extent (Comiso et al. 2008) and an earlier melt onset (Maslanik et al. 2011) are causing light intensity to 
increase within and below the ice-covered Arctic Ocean during the spring season (Nicolaus et al. 2012). This changing light regime may also be influenced by winter and springtime decreases in stratospheric ozone over the Arctic (Rex et al. 1997, Manney et al. 2011). Therefore, the Arctic sea ice-associated biota is at a time of particular vulnerability to the increasing UV radiation. Studies on the capacity of primary producers in the Arctic to endure light stressor through the production of MAAs and other UV-absorbing compounds are thus an important step in our ability to predict and model ecosystem response to climate warming.

When studying the absorption spectra of algal samples taken from landfast first-year sea ice in a coastal Arctic bay, Mundy et al. (2011) noted that the wavelengths of peak UV absorption (310, 320-334, and $360 \mathrm{~nm}$ ) corresponded to the absorption peaks of a variety of MAAs, with much higher absorbance observed in melt-pond algal samples than those within the sea ice. They also observed different UV wavelength peaks in different algal communities. Based on these results, we hypothesize that algae in different sea ice-associated environments will produce variable quantities and types of MAAs depending on their habitat exposure to light. We report here measurements of MAAs in Arctic algal communities associated with bottom ice, melt water, and water column habitats over the spring melt transition and in relation to changing environmental conditions. More specifically our study aimed to (1) determine the presence or absence of MAAs in ice and ice-covered Arctic waters; (2) compare MAA composition in the different ice-associated habitats; (3) investigate the effect of snow cover on MAA production; and (4) relate the presence of specific MAAs to key algal taxa.

\section{MATERIALS AND METHODS}

\section{Study area}

Samples from the bottom ice, surface melt ponds, the sea ice-water interface below melt ponds, and the underlying seawater were collected from Allen Bay, Nunavut, Canada, at an ice camp field site $\left(74^{\circ} 43^{\prime} \mathrm{N}, 9^{\circ} 09^{\prime} \mathrm{W}\right)$ as part of the Arctic-ICE (Ice Covered Ecosystem) 2011 field program. The camp was located on smooth landfast first-year sea ice over a water depth of $60 \mathrm{~m}$; details of the study site can be found elsewhere (Campbell et al. 2014, Galindo et al. 2014, Landy et al. 2014). The study period covered the transition from a snow-covered surface through to formation of melt ponds from 6 May to 24 June 2011. Daily-averaged air temperatures at the study site ranged from -16 to $4.1^{\circ} \mathrm{C}$ as the study progressed (see Fig. 2a). Site-averaged sea ice thickness was near constant at $140 \mathrm{~cm}$ from the beginning of the study until 12 June and decreased to $100 \mathrm{~cm}$ by 24 June (Galindo et al. 2014). Site-averaged snow depth varied between 15 and $20 \mathrm{~cm}$ before decreasing abruptly following rainfall events of 1.0 and $0.8 \mathrm{~mm}$ on 10 and 12 June, respectively, leading to the rapid development of melt ponds (Campbell et al. 2014). Sea ice break-up occurred on 27 June, shortly after termination of the study.

\section{Sample collection}

Landfast sea ice core samples were taken every $4 \mathrm{~d}$ as part of a regular sampling schedule during the study period. All sampling occurred within an approximate $500 \times 500 \mathrm{~m}$ area with new sampling sites chosen daily within a $50 \mathrm{~m}$ radius to include locations of thin $(<10 \mathrm{~cm})$, medium $(10-18 \mathrm{~cm})$, and thick $(>18 \mathrm{~cm}$ ) snow depths. As the snow cover melted, the thin and thick snow sites transitioned to melt pondand white ice-covered sites, respectively, and the medium snow sites were no longer sampled. Ice cores were collected by a Mark II Kovacs core barrel (i.d. $=9 \mathrm{~cm}$ ), and the bottom $3 \mathrm{~cm}$ was used for ice algal samples. Two to 3 ice cores were pooled in isothermal cooler jugs and melted in the dark over 18-24 $\mathrm{h}$ with the addition of $0.2 \mu \mathrm{m}$-filtered seawater (FSW) at a volume ratio of approximately 3:1 (FSW: ice melt) to minimize osmotic shock of the microbial community and associated release of MAAs from cells while melting (Garrison \& Buck 1986). An extra core (non FSW-diluted) at each site was collected for bulk salinity measurement.

Sampling of the surface melt ponds and sea icewater interface below melt ponds commenced on 12 June and occurred every $4 \mathrm{~d}$ to study their spatial and temporal variability. Spatial sampling involved selecting 3 to 4 melt ponds in the vicinity of the ice core collection site providing true replicates. Melt ponds were selected based on the criteria that no connection existed between them by surface drainage channels and that they had a depth of at least $3 \mathrm{~cm}$. Slurp guns were used to collect surface melt pond samples. For collecting samples at the sea ice-water interface, auger holes were made through white ice adjacent to the melt pond, and the water samples were collected at the ice-water inter- 
face directly below the melt pond by a battery-operated submersible pump (Cyclone ${ }^{\circledR}$ ) positioned by an under-ice arm. The habitat sampled by this method will hereinafter be referred to as the interface below melt ponds. This technique allowed us to sample the under-ice melt layer as it progressed to inverted melt ponds (Eicken et al. 2002).

Water column samples at 2, 5, and $10 \mathrm{~m}$ depths below the ice were collected every $4 \mathrm{~d}$ between 7 to 23 June using Niskin bottles deployed through a large ice hole within a heated tent (no replicates).

\section{Sample analysis}

Salinity of water and non FSW-diluted melted sea ice core samples was measured with a handheld conductivity meter (Cond 330i, WTW). Downwelling irradiance $\left(\mathrm{W} \mathrm{m} \mathrm{m}^{-2} \mathrm{~nm}^{-1}\right.$ ) was coincidentally measured at the surface and under the sea ice at each snow depth site using a dual head VIS-NIR spectrometer (350-1050 nm at $1.4 \mathrm{~nm}$ band width; FieldSpec Pro, Analytical Spectral Devices) with cosine corrected sensors and positioned by an under-ice arm (Campbell et al. 2014). Integrated percent transmittance $(\% T)$ over the MAA-relevant band of UV radiation (350-360 nm; data were not available for $\lambda<$ $350 \mathrm{~nm}$ ) was calculated using:

$$
\% T=\frac{\int E z_{\lambda} \mathrm{d} \lambda}{\int E 0_{\lambda} \mathrm{d} \lambda} \times 100 \%
$$

where $\lambda$ is wavelength and $E z_{\lambda}$ and $E 0_{\lambda}$ are spectral transmitted and incident irradiance, respectively.

Water and melted FSW-diluted ice core samples were subsampled for determining protist taxonomy, concentrations of chlorophyll a ( $\mathrm{chl}$ a) and abundance of MAAs. Subsamples for identification and enumeration of diatoms, dinoflagellates and flagellates were preserved with acidic Lugol's solution (Parsons et al. 1984) and stored in the dark at $4^{\circ} \mathrm{C}$ until analysis. Cells $\geq 2 \mu \mathrm{m}$ in size were identified to the lowest possible taxonomic rank (Poulin \& Cardinal 1982a,b, 1983, Medlin \& Hasle 1990, Medlin \& Priddle 1990, Thomsen 1992, Poulin 1993, Tomas 1997, von Quillfeldt 1997) using an inverted microscope (Zeiss Axiovert 10) equipped with phase contrast optics (Lund et al. 1958). At least 400 cells were enumerated over a minimum of 3 transects. The abundance of each taxon was computed according to the equation described by Horner (2002).

Chl a was fluorometrically determined from 25$1000 \mathrm{ml}$ of subsamples filtered onto a Whatman GF/F glass fiber filter $(0.7 \mu \mathrm{m}$ nominal pore size $)$ using the methods of Parsons et al. (1984). Filters were immediately placed into $10 \mathrm{ml}$ of $90 \%$ acetone and left at $4^{\circ} \mathrm{C}$ for $18-24 \mathrm{~h}$ in the dark for pigment extraction. Fluorescence of the extracted pigments was measured before and after acidification with $5 \% \mathrm{HCl}$ using a 10-005R Turner Designs fluorometer. Chl a was calculated using the equation described by HolmHansen et al. (1965).

For MAA determination, 25-500 ml subsamples and daily field blanks (FSW) were filtered onto Whatman $\mathrm{GF} / \mathrm{F}$ filters and stored at $-80^{\circ} \mathrm{C}$ until analysis in the Manitoba Chemical Analysis Laboratory, Winnipeg, MB. The high performance liquid chromatography (HPLC) method used to quantify MAAs followed the procedure of Carreto et al. (2005). Briefly, field samples (filters containing particulate fractions of the water/melted ice samples) were taken from storage $\left(-80^{\circ} \mathrm{C}\right.$ freezer) and placed in a freezer at $-20^{\circ} \mathrm{C}$ for $12-24 \mathrm{~h}$ prior to analysis. The samples were extracted via serial extraction with 3 aliquots of $2 \mathrm{ml}$ of $100 \%$ methanol with the assistance of sonication in an ice bath. The $6 \mathrm{ml}$ of solvent was evaporated off with nitrogen and then reconstituted with $0.5 \mathrm{ml}$ of the starting mobile phase $(0.2 \%$ trifluoroacetic acid in water adjusted to $\mathrm{pH}=3.15)$. Lab blanks and $200 \mathrm{mg}$ of seaweed Porphyra sp. were extracted and run with each batch of samples as a quality control. Clean-up was done using ultracentrifugation filtration (Amicon $0.5 \mathrm{ml} 100 \mathrm{kDa}$, Fisher Scientific), and the filtrates were analyzed within $24 \mathrm{~h}$ on a Varian Prostar HPLC with a diode array detector (DAD) at a flow rate of $1 \mathrm{ml} \mathrm{min}{ }^{-1}$. The columns used were a C18 HL Alltima HP $150 \mathrm{~mm} \times 4.6 \mathrm{~mm} \times 5 \mu \mathrm{m}$ (Fisher Scientific) in tandem with a C18 UG 120A $250 \mathrm{~mm} \times$ $4.6 \mathrm{~mm} \times 5 \mu \mathrm{m}$ (JM Science). UV absorbance was monitored in the wavelength range of $280-400 \mathrm{~nm}$ with a particular focus on 360 and $330 \mathrm{~nm}$ to measure individual MAAs, as well as at $270 \mathrm{~nm}$ to monitor for interfering contaminants that absorb at lower wavelengths (Carreto et al. 2005). Due to the lack of MAA standards, the initial tentative identification of MAAs was simply based on comparing the values of retention time and $\lambda_{\max }$ with those reported in the literature.

About 1 yr after the initial HPLC-DAD analysis, we obtained 3 MAA standards (shinorine, palythine and porphyra-334, Fig. 1) from Dr. A. Matsuoka of Université Laval (Quebec, Canada). This allowed us to carry out further identification of the MAAs in our samples on a HPLC (Agilent 1200)-electrospray ionization (ESI)-triple quadrupole mass spectrometer (MS) (Agilent 6410b) (i.e. HPLC-ESI-MS) in the Ultra-Clean Trace Elements Laboratory (UCTEL) at 
the University of Manitoba. The HPLC method was similar to the one described above, with the exception that trifluoroacetic acid in the mobile phase was replaced by formic acid to optimize ESI as suggested by Carignan et al. (2009). A multiple reaction monitoring (MRM) method was developed with ESI in positive mode (gas temperature $=325^{\circ} \mathrm{C}$, gas flow $=$ $111 \mathrm{~min}^{-1}$, and nebulizer pressure $=60 \mathrm{psi}$ ) based on the mixed solution of shinorine, palythine and porphyra-334. In brief, we first identified the major parent ion of each of the MAA standards (mass to charge ratio $\mathrm{m} / \mathrm{z}=333,245$, and 347 for shinorine, palythine and porphyra-334, respectively) under a fragmentor voltage of $100 \mathrm{~V}$ and then monitored the major product ion $(m / z=230,186$, and 303 for shinorine, palythine and porphyra-334, respectively) at a collision energy of $20 \mathrm{eV}$. The MRM method was then used to confirm the identities of the MAAs in a sub-set of the previously analyzed samples.

\section{Statistical analysis}

Statistical analysis was performed with Prism (version 5.0a, GraphPad). Two-tailed Student's $t$-test was used to evaluate the difference between MAA nominal concentrations in various communities, and Pearson correlation was done to evaluate the relationship between taxonomic groups and MAAs. Significance threshold was set at $\mathrm{p}<0.05$.

\section{RESULTS}

During the study period, daily-averaged air temperature steadily increased with some short-lasting, relatively stable periods (Fig. 2a). The averaged temperatures first reached above $0^{\circ} \mathrm{C}$ on 9 June and remained consistently near or above that value thereafter. High temperatures, along with 2 rainfall events on 10 and 12 June, resulted in rapid melting of snow, development of surface melt ponds and an underice melt layer, and thinning of sea ice (Campbell et al. 2014, Galindo et al. 2014). Percent transmittance of MAA-relevant UV radiation (350$360 \mathrm{~nm}$ ) through snow and sea ice was $<1 \%$ until 4 and 8 June, respectively, and increased rapidly thereafter, reaching 19.0 and $5.9 \%$ by the end of the study under thin (melt pond) and thick (white ice) snowcovered sites, respectively (Fig. 2b). The snow and then sea ice melt progression resulted in a slight increase in salinity in the surface melt ponds and a decrease in salinity of the $3 \mathrm{~cm}$ bottom ice, the interface below melt ponds, as well as the top $2 \mathrm{~m}$ of the underlying water column (Fig. 3a-c).

Bottom ice chl a concentrations varied between 400 and $1000 \mu \mathrm{g} \mathrm{l}^{-1}$ from 6 May to 4 June, then sharply decreased to $<10 \mu \mathrm{g} \mathrm{l}^{-1}$ after 16 June (Fig. 3d). Chl a concentrations in the surface melt ponds were consistently $<0.5 \mu \mathrm{g} \mathrm{l^{-1 }}$ (Fig. 3e). The interface below melt ponds had a much higher chl a concentration $\left(11.7 \mu \mathrm{g} \mathrm{l}^{-1}\right)$ on 12 June at the beginning of melt pond development but decreased rapidly to $<0.5 \mu \mathrm{g} \mathrm{l}^{-1}$ by 20 June (Fig. 3e). In the underlying water column, chl a

Fig. 2. (a) Daily-averaged air temperature and (b) percent transmission of a narrow UV band (350-360 nm) through sea ice in Allen Bay, Nunavut, Canada, between 6 May and 24 June 2011. Percent transmission of a broader UV band (350-400 nm) followed the same trend. Dashed vertical lines indicate 2 rainfall events on 10 and 12 June. In (a), error bars are SD 

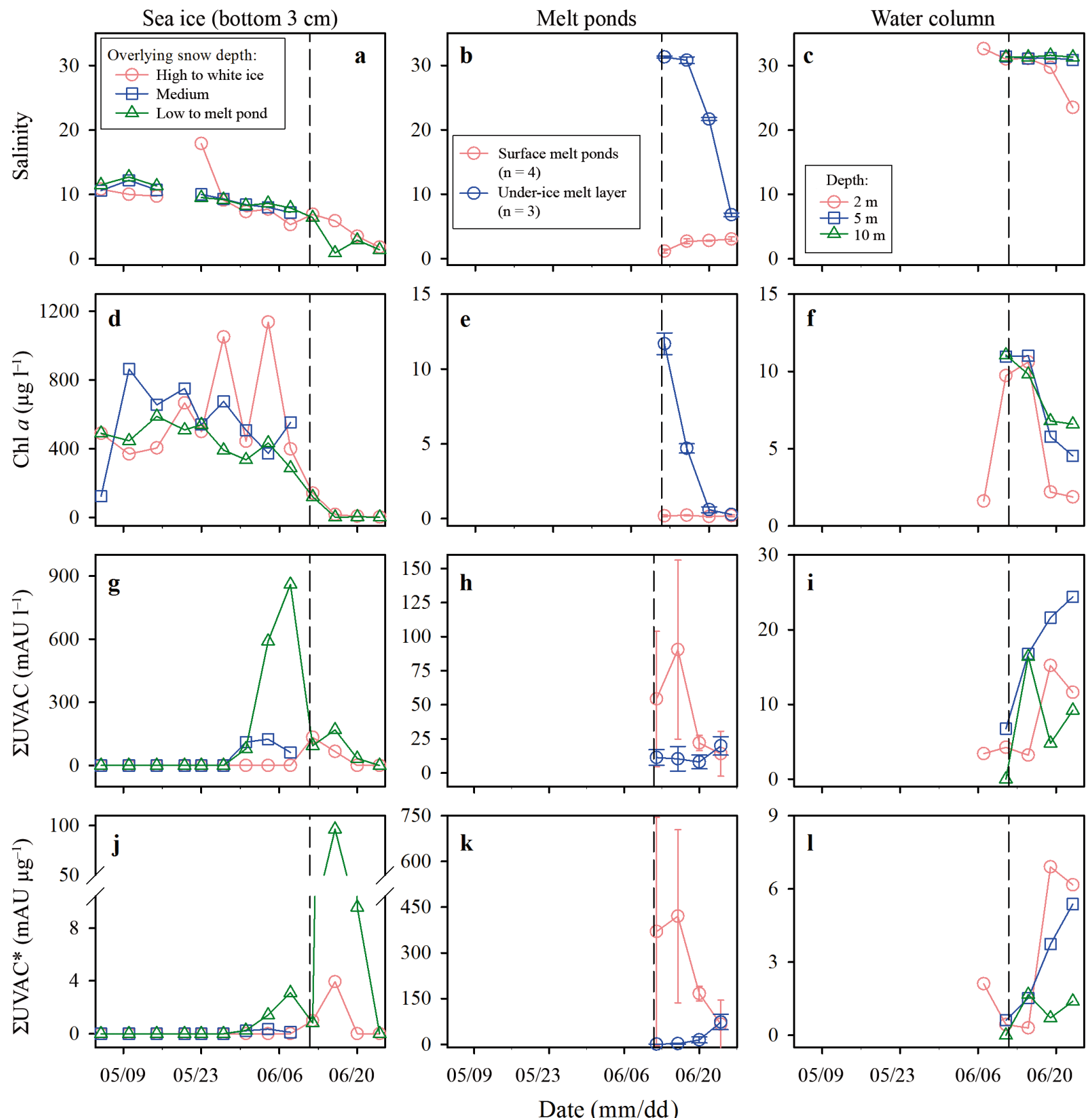

Fig. 3. Time series of $(\mathrm{a}, \mathrm{b}, \mathrm{c})$ salinity, $(\mathrm{d}, \mathrm{e}, \mathrm{f})$ concentration of chlorophyll $a$ (chl $a),(\mathrm{g}, \mathrm{h}, \mathrm{i})$ nominal concentration of total UV-absorbing compounds ( $\sum$ UVAC), and $(\mathrm{j}, \mathrm{k}, \mathrm{l}) \mathrm{chl}$ a-normalized $\sum \mathrm{UVAC}$ concentration ( $\sum \mathrm{UVAC}^{*}$ ) in the $3 \mathrm{~cm}$ bottom ice (left panels), melt ponds (middle panels) and underlying water column (right panels) in Allen Bay, Nunavut, Canada, between 6 May and 24 June 2011. Vertical dashed lines show when melt ponds started to develop following temperature rise and 2 rainfall events (June 12). In (b,e,h,k), error bars are SD. UVAC concentrations include the 3 mycosporine-like amino acids (shinorine, palythine, porphyra-334) and 3 unknown UV-absorbing compounds (U1, U2, U3)

concentrations were $<0.5 \mu \mathrm{g} \mathrm{l}^{-1}$ at the beginning of the sampling period (Galindo et al. 2014), increased to a maximum of $11 \mathrm{\mu g} \mathrm{l}^{-1}$ on 11 June, and decreased thereafter (Fig. 3f). A subsurface chlorophyll maximum began to form at a depth of 5-10 $\mathrm{m}$ at the end of the sampling period (Galindo et al. 2014).
For the analysis of MAAs, various peaks were present in the HPLC chromatograms of bottom ice samples collected after 31 May, and in most of the melt pond and water column samples collected. In total, 6 peaks were most consistently identified from HPLC chromatograms (see Fig. 4c-e for examples). Their 

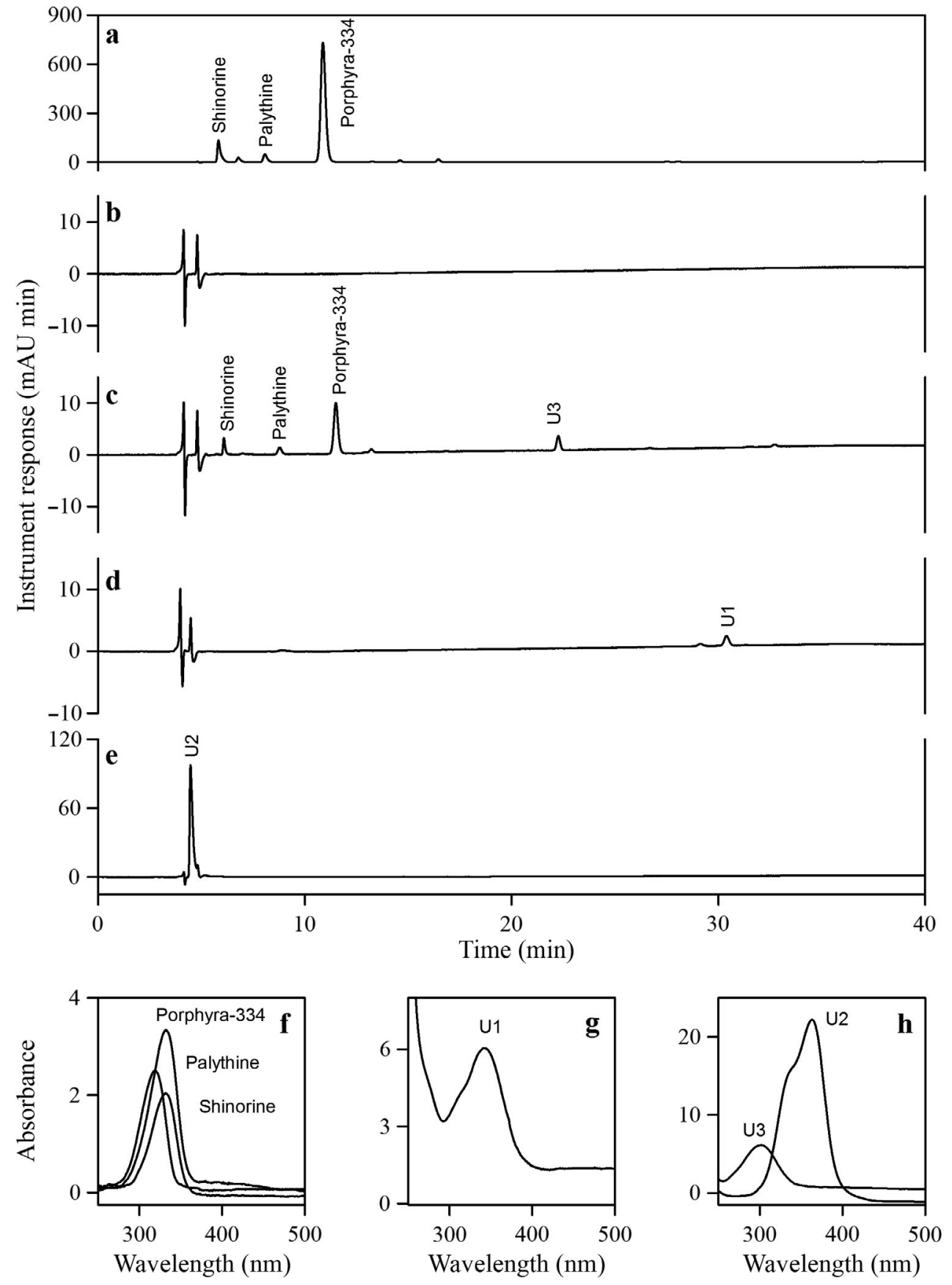

Fig. 4. Chromatograms of (a) seaweed Porphyra sp. at $330 \mathrm{~nm}$, (b) field blank (filtered seawater procedural blank) at $330 \mathrm{~nm}$, (c) water column sample at $330 \mathrm{~nm}$, (d) under-ice melt layer sample at $360 \mathrm{~nm}$, and (e) surface melt pond sample at $360 \mathrm{~nm}$. Bottom panels $(\mathrm{f}, \mathrm{g}, \mathrm{h})$ show UV-visible absorption spectra of 3 mycosporine-like amino acids (shinorine, palythine, porphyra-334) and 3 unknown UV-absorbing compounds (U1, U2, U3). mAU: milli absorbance units

$\lambda_{\max }$ ranged from 300 to $363 \mathrm{~nm}$ (Fig. 4f-h), which fell within the general range of those reported for MAAs $(309-362 \mathrm{~nm})$ with the exception of U3 $\left(\lambda_{\max }=\right.$ $300 \mathrm{~nm})$. Based on the comparison of retention times and $\lambda_{\max }$ with those reported in Carreto et al. (2005) and on the calibration with the seaweed Porphyra sp.
(Fig. 4a), 4 peaks were tentatively assigned to shinorine $\left(\lambda_{\max }=332 \mathrm{~nm}\right)$, palythine $\left(\lambda_{\max }=320 \mathrm{~nm}\right)$, porphyra-334 $\left(\lambda_{\max }=333 \mathrm{~nm}\right)$, and palythene $\left(\lambda_{\max }=\right.$ $358 \mathrm{~nm}$ ). The identities of shinorine, palythine and porphyra-334 were later confirmed by HPLC-ESI-MS by monitoring the major mass transition of the corre- 
sponding standards $(\mathrm{m} / \mathrm{z} \quad 333 \rightarrow 230$ for shinorine, $245 \rightarrow 186$ for palythine, and $347 \rightarrow 303$ for porphyra334 ) in a sub-set of the samples. Although the fourth compound $\left(\lambda_{\max }=358 \mathrm{~nm}\right)$ is most likely palythene, we were not able to structurally confirm it due to the lack of an appropriate standard and due to the small quantity of the samples; it will be referred to as UVabsorbing compound Unknown 1 (U1). The retention time and absorption spectrum of the remaining 2 peaks could not be matched to any of the 20 MAAs reported in Carreto et al. (2005) and hereafter are referred to as UV-absorbing compounds Unknown 2 (U2; retention time $=4.1 \mathrm{~min}, \lambda_{\max }=363 \mathrm{~nm}$ with a second $\lambda_{\max }=337 \mathrm{~nm}$ ) and Unknown 3 (U3; retention time $=19 \mathrm{~min}, \lambda_{\max }=300 \mathrm{~nm}$ ). Structural identification of U2 and U3 by HPLC-ESI-MS was not successful due to the small quantity of our samples. Due to the lack of respective standards for calibration at the time of the analysis, accurate quantification was not possible, and therefore the concentrations of shinorine, palythine, porphyra-334, U1, U2, and U3 are reported nominally as their UV absorption capacity measured in $\mathrm{mAU}^{-1}$ (milli absorbance units per liter of water or melted ice). The nominal concentration of total UV-absorbing compounds (UVAC), ¿UVAC, was calculated as the sum of shinorine, palythine, porphyra-334, and U1-3. As all the UVAC measurements were made on particles retained on filters; the concentrations reported herein refer to those in the particulate phase (i.e. within cells), not in the dissolved phase.

In the bottom ice, no UVACs were detected prior to 31 May at both thin and mid snow-covered sites. UVACs increased rapidly afterwards, reaching a peak $\Sigma$ UVAC value of $860 \mathrm{mAU} \mathrm{l}^{-1}$ on 8 June at thin snow-covered sites and $125 \mathrm{mAU} \mathrm{l}^{-1}$ on 31 May at mid snow-covered sites (Fig. 3g). At thick snow-covered sites, UVACs were not detected in the bottom ice horizon until 12 June with a SUVAC value of $133 \mathrm{mAU} \mathrm{l}^{-1}$ (Fig. 3g). At all sites, UVAC nominal concentrations in the bottom ice decreased quickly following the development of melt ponds and became undetectable by 24 June. UUVAC nominal concentrations in the surface melt ponds were between 65 and $90 \mathrm{mAU}^{-1}$ following the melt pond development at the surface of the ice, but decreased rapidly to $\sim 10 \mathrm{mAU}^{-1}$ as melting and drainage progressed (Fig. 3h). In contrast, $\Sigma$ UVAC nominal concentrations in the interface water below the melt ponds were initially below $15 \mathrm{mAU} \mathrm{l}^{-1}$ and increased as drainage of the surface melt ponds progressed (Fig. 3h). By the end of the study $\Sigma$ UVAC nominal concentrations in the interface water below the melt ponds were not different from those in the surface melt ponds ( $\mathrm{p}=$ $0.90, \mathrm{n}=3, t$-test). In the underlying water column ¿UVAC nominal concentrations ranged from below the detection limit to $24 \mathrm{mAU} \mathrm{I}^{-1}$, with concentrations generally higher at $5 \mathrm{~m}$ depth than at the 2 and $10 \mathrm{~m}$ depths (Fig. 3i).

In order to examine the relative production of UVACs per algal biomass, chl a-specific $\Sigma U V A C$ concentrations were calculated ( $\Sigma \mathrm{UVAC}^{*}$; mAU $\mathrm{mg}^{-1}$ chl a). Although the bottom ice under thin snow cover had the highest $\sum$ UVAC nominal concentrations, surface melt pond algae had the highest $\sum U_{V A C}^{*}$, $420 \mathrm{mAU} \mathrm{\mu g}^{-1}$ (Fig. 3k). Comparable $\sum \mathrm{UVAC}^{*}$ concentrations were found in the bottom ice algae (up to

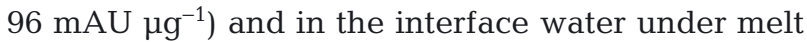
ponds (Fig. 3j,k). Much lower $\sum$ UVAC $^{*}$ concentrations were observed in the water column $(2-10 \mathrm{~m}$ water depths; up to $6.9 \mathrm{mAU} \mu \mathrm{g}^{-1}$ ), and in the bottom ice under white ice (up to $3.8 \mathrm{mAU} \mathrm{\mu g}^{-1}$ ). Bottom ice under medium to thick snow cover had the lowest $\sum$ UVAC $^{*}\left(<0.5 \mathrm{mAU}^{\mathrm{N}} \mathrm{g}^{-1}\right.$; Fig. 3j).

In terms of UVAC composition, the most abundant MAAs in all the samples were shinorine and porphyra-334 (Fig. 5). The unknown UV-absorbing compound, U2, while present in the bottom ice under melt pond and in the under-ice melt layer, contributed greatly in surface melt ponds. U2 had the highest chl a-specific nominal concentration of UVabsorbing compounds observed (88-560 mAU $\mu \mathrm{g}^{-1}$ ), followed by shinorine, and then by other MAAs and U3 with relatively minor chl a-specific nominal concentrations. The diversity of UVAC composition was the highest in the under-ice melt layer and lowest in surface melt ponds.

In samples collected for taxonomic analyses, the total abundance of protists (i.e. sum of diatoms, dinoflagellates and flagellates) was, on average, $0.29 \times$ $10^{6}$ cells $1^{-1}$ in surface melt ponds (June), $114 \times 10^{6}$ cells $1^{-1}$ in bottom ice under thick snow cover (May and June) and $5.38 \times 10^{6}$ cells $1^{-1}$ and $4.53 \times 10^{6}$ cells $\mathrm{l}^{-1}$ in the water column at 5 and $10 \mathrm{~m}$ depth, respectively (June). The surface melt pond protist community was numerically dominated by flagellates (75\%), among which a large proportion (88\%) was unidentified taxa. The rest of the community was composed of pennate $(16 \%)$ and centric diatoms $(7 \%)$, and dinoflagellates (2\%) (Fig. 6a). The bottom ice community was dominated by pennate diatoms (72\%) with the pan-Arctic endemic species Nitzschia frigida Grunow making up 14-46\% of the total cell abundance. Other protist groups present in the bottom ice horizon were flagellates $(25 \%)$, centric diatoms $(2.5 \%)$ and dinoflagellates $(0.5 \%)$ (Fig. 6b). As in the 


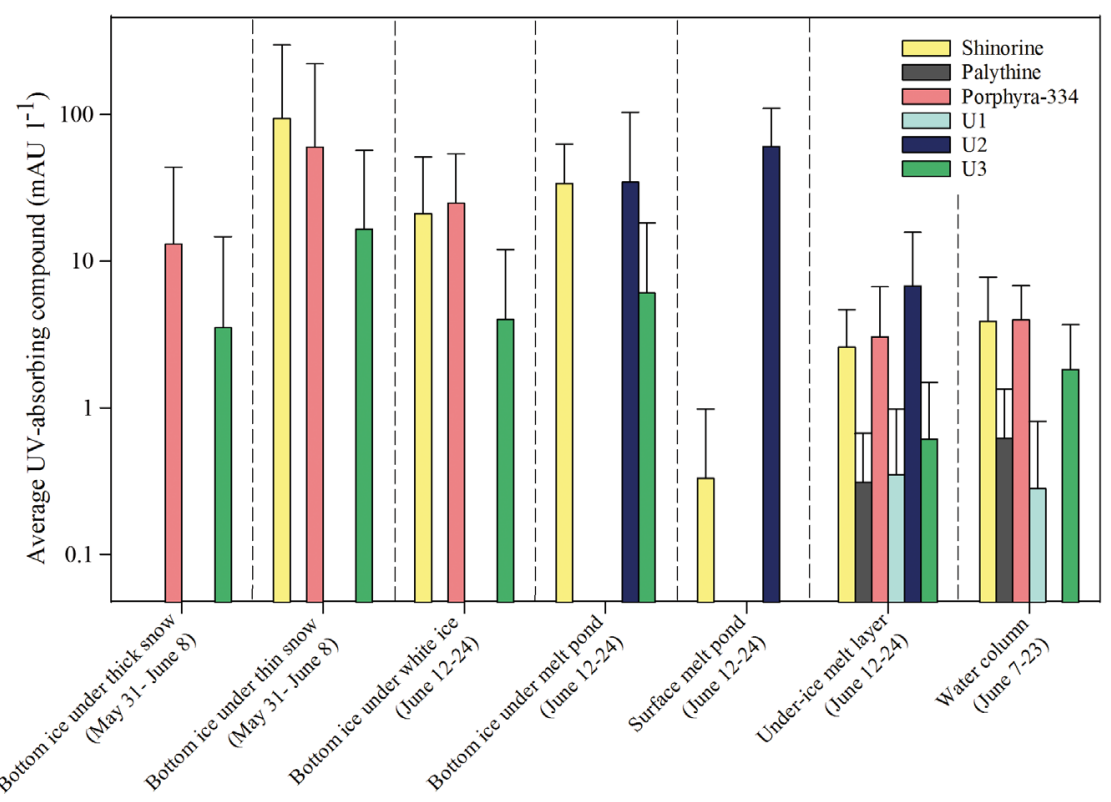

Fig. 5. Average UV-absorbing compound concentrations from samples collected from different habitats in Allen Bay, Nunavut, Canada, between 31 May and 24 June 2011. Error bars are SD

\section{DISCUSSION \\ Identity of MAAs in ice-covered environments}

The 3 MAAs, shinorine, palythine and porphyra-334, identified in the ice-covered water column and underice melt layer in this study, have all been previously reported in polar waters (Karentz et al. 1991, Whitehead et al. 2001, Ryan et al. 2002, Ha et al. 2012). Of particular relevance to this study in the Arctic Ocean is Ha et al. (2012), which detected 5 MAAs in phytoplankton samples collected near Svalbard, namely shinorine, palythine, porphyra-334, asterina-330 and mycosporine-glycine. In contrast, there was no conclusive evidence of asterina-330 and mycosporine-glycine in any of our samples. Another UVAC, U1 (most likely palythene), was found to be present in our water column and

bottom ice, pennate diatoms were predominant in the water column community at $5 \mathrm{~m}$ (85\%) (Fig. 6c), but Fossula arctica Hasle, Syvertsen \& von Quillfeldt was the main species representing $42-76 \%$ of the total cell abundance. The rest of the community was composed of flagellates $(13 \%)$, centric diatoms $(1.2 \%)$, and dinoflagellates $(0.8 \%)$ (Fig. 6c). under-water melt layer samples but was not reported in Ha et al. (2012). Similarly, while shinorine, palythine and porphyra-334 were detected in the sea ice of the Baltic Sea (Uusikivi et al. 2010, Piiparinen et al. 2015), only shinorine and porphyra-334 were identified in our bottom sea ice samples. Such difference could be due to the presence of different organisms a) Melt ponds

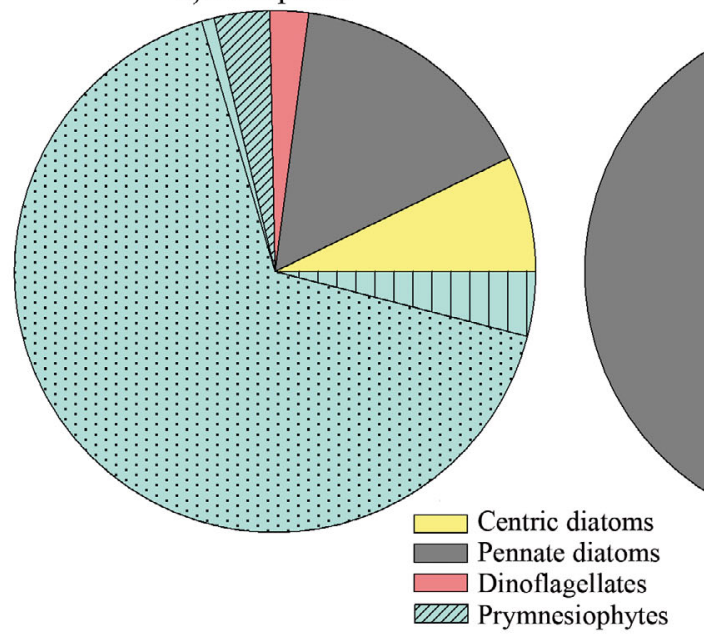

b) Bottom ice

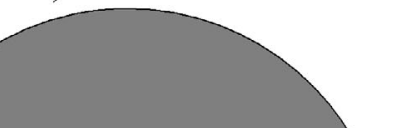

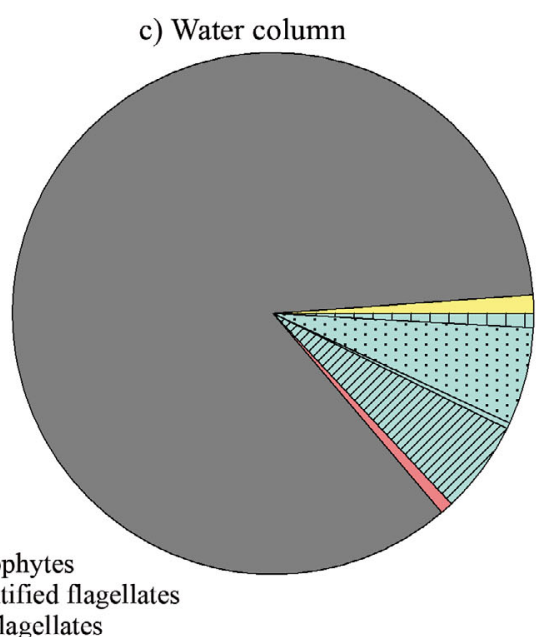

Fig. 6. Average relative abundance of 6 protist $(>2 \mu \mathrm{m})$ groups (centric diatoms, pennate diatoms, dinoflagellates, prymnesiophytes, prasinophytes, unidentified flagellates and other flagellates) in (a) melt ponds (June), (b) bottom ice (bottom $3 \mathrm{~cm}$ of sea ice) under a thick snow cover (>15 cm, May and June), and (c) water column (5 m depth, June) in Allen Bay, Nunavut, Canada. The 'other flagellate' group comprises chlorophytes, chrysophytes, cryptophytes, dictyochophytes, euglenophytes and raphidophytes. Note that we did not observe dictyochophytes in melt pond samples and chrysophytes, dictyochophytes and raphidophytes in bottom ice samples 
in different regions. For example, Phaeocystis sp. was a dominant phytoplankton species observed in Ha et al. (2012), whereas our water column samples were dominated by pennate diatoms (mainly F. arctica) with Phaeocystis sp. only present at very low abundances (3\% of total flagellates and $0.3 \%$ of total protist cells). Palythine was detected in Baltic Sea ice that was thinner $(33-40 \mathrm{~cm})$ than the ice sampled in our study $(100-140 \mathrm{~cm})$. In sea ice, shorter wavelength radiation in the UV spectrum is attenuated more rapidly than longer wavelengths. It is possible that in the case of our samples the bottom ice algae had less need for palythine, which has an absorption maximum at a shorter wavelength $(320 \mathrm{~nm})$.

The 2 other unknown UV-absorbing compounds U2 $\left(\lambda_{\max }=363 \mathrm{~nm}\right)$ and U3 $\left(\lambda_{\max }=300 \mathrm{~nm}\right)$ absorbed light at the extreme end and outside, respectively, of the $\lambda_{\max }$ range of the known MAAs. U2 also had a shoulder in the absorption curve centered at $337 \mathrm{~nm}$ (Fig. 3h), similar to an unknown compound recently reported in the Baltic Sea ice upon exposure to high UV radiation (Piiparinen et al. 2015). Piiparinen et al. (2015) speculated the identity of this unknown to be M335/360, a condensation product of shinorine and palythene as reported in Carreto et al. (2001). However, the absorption spectrum and chromatographic retention for M335/360 does not match that of U2. While M335/360 has a large peak at $335 \mathrm{~nm}$ and a shoulder at $360 \mathrm{~nm}$, U2 had a large peak at $363 \mathrm{~nm}$ and a shoulder at $337 \mathrm{~nm}$. Although the different HPLC methods used in our study and in Carreto et al. (2001) do not allow for a direct comparison of retention times, it is important to note that M335/360 eluted off their column (Alltima Alltech C18) after shinorine, whereas U2 was the first to elute off our columns. This suggests U2 is more polar than M335/ 360 . The only known MAAs that have an absorption maximum close to $360 \mathrm{~nm}$ are usujirene $\left(\lambda_{\max }=\right.$ $357 \mathrm{~nm})$, palythene $\left(\lambda_{\max }=360 \mathrm{~nm}\right)$, and euhalothece-362 $\left(\lambda_{\max }=362 \mathrm{~nm}\right)$. It is possible that U2 could be a condensation product of one of these compounds and another MAA, although the large difference in retention times between $\mathrm{U} 2$ and palythene or usujirene in our analysis suggests that neither palythene nor usujirene can be a component of U2. Euhalothece-362 is also only weakly acidic and has higher retention to C8-bonded silica than strongly acidic MAAs such as shinorine, porphyra-334 and mycosporine-2-glycine (Volkmann et al. 2006). U2 demonstrates similar retention properties to strongly acidic MAAs; from this observation we propose that U2 cannot be euhalothece-362 although it may be a condensation product of this compound and a strongly acidic MAA. To date, euhalothece-362 has only been identified in the halophilic cyanobacterium, Euhalothece sp. (Oren 1997, Volkmann et al. 2006), but it is suspected to be more widespread in unicellular cyanobacteria (Volkmann et al. 2006). While our understanding of MAAs in marine cyanobacteria is poor, the possibility of MAA association with symbiotic cyanobacteria contained within heterotrophic dinoflagellates or diatoms has been reported from a study along a surface water meridional transect of the Atlantic Ocean (Llewellyn et al. 2012). Cyanobacteria have recently been observed in Arctic marine habitats including seawater (Bowman et al. 2012, Díez et al. 2012), first-year (Mundy et al. 2011) and multi-year sea ice (Bowman et al. 2012), and sea ice brine (Díez et al. 2012). No filamentous cyanobacteria of $\geq 2 \mu \mathrm{m}$ in size were observed by inverted microscopy in any of our samples. Although we did not enumerate picocyanobacteria cells $(<2 \mu \mathrm{m})$ during this study, we did find a very small number of picocyanobacteria, by flow cytometry, in melt ponds, bottom ice and water column from the same site in a subsequent study in late June 2012. Future structural identification is needed to determine if U2 is a condensation product of euhalothece-362 and another MAA, a novel, previously unreported MAA, or a nonMAA UV-absorbing compound.

U3 had an unusually short $\lambda_{\max }$ of $300 \mathrm{~nm}$. In comparison, the MAA 'backbone' 4-deoxygadusol has a $\lambda_{\max }$ of $268 \mathrm{~nm}$, and mycosporine-glycine, which is among the least conjugated MAA, has a $\lambda_{\max }$ of 310 nm (Carreto et al. 2005, Gao \& Garcia-Pichel 2011). We suggest it might be structurally impossible to have an MAA with a $\lambda_{\max }$ of $300 \mathrm{~nm}$, and therefore, U3 is likely a novel, non-MAA, UV-absorbing compound that requires structural elucidation.

\section{Estimate concentrations of MAAs}

Since we did not obtain the MAA standards until $1 \mathrm{yr}$ after the analysis was done, we were not able to directly determine the concentrations of MAAs in our samples. To compare with the literature data, we estimated the concentrations of the 3 MAAs from the absorbance, the pathlength of the flow cell $(1 \mathrm{~cm})$, the published molar extinction coefficient and the molecular weight of $44700 \mathrm{l} \mathrm{mol}^{-1} \mathrm{~cm}^{-1}$ and $332 \mathrm{~g}$ $\mathrm{mol}^{-1}$ for shinorine, $36200 \mathrm{l} \mathrm{mol}^{-1} \mathrm{~cm}^{-1}$ and $244 \mathrm{~g}$ $\mathrm{mol}^{-1}$ for palythine, and $42300 \mathrm{l} \mathrm{mol}^{-1} \mathrm{~cm}^{-1}$ and $346 \mathrm{~g}$ $\mathrm{mol}^{-1}$ for porphyra-334 (Gröniger et al. 2000, Carreto et al. 2011). The estimated concentrations of shinorine ranged between 0.1 and $21.9 \mathrm{\mu g} \mathrm{l}^{-1}$ and were 
the highest in the bottom sea ice beneath a low snow cover. Estimated concentrations of platythine did not exceed $0.1 \mu \mathrm{g}^{-1}$ throughout the study, and trace levels were seen in the water column at all depths sampled. Estimated concentrations of porphyra-334 were between 0.1 and $19.9 \mu \mathrm{g} \mathrm{l}^{-1}$. Assuming $\mathrm{U} 1$ is palythene with a molar extinction coefficient of $50000 \mathrm{l}$ $\mathrm{mol}^{-1} \mathrm{~cm}^{-1}$ (Gröniger et al. 2000, Carreto et al. 2011), its estimated concentrations remained at trace levels $\left(<0.1 \mu \mathrm{g} \mathrm{l}^{-1}\right)$ throughout the study and were confined to the water column. These values are in a similar range to those estimated in Baltic Sea ice (1.1-2.5 $\mu \mathrm{g}$ $1^{-1}$ total MAAs in bottom sea ice) (Piiparinen et al. 2015) as well as those measured in the Arctic waters near Svalbard (3.1-25.5 $\mathrm{mg} \mathrm{l}^{-1}$ in the water column) (Ha et al. 2012). If we compare the ratio of the total estimated MAA concentrations to chl a concentrations $\left(\mu \mathrm{g} \mathrm{l}^{-1}\right)$, the ratios in our bottom ice samples are up to 0.6, which is much higher than those reported in Baltic Sea ice $(0.008 \pm 0.004$ SD) (Piiparinen et al. 2015). The high ratios that we observed are during the late stages of sea ice melt, and this seasonal transition was not captured in the work of Piiparinen et al. (2015). Caution is warranted when estimating MAA concentrations based on their molar extinction coefficients, as the coefficients are known to vary with analytical conditions (e.g. pH, temperature) (Zhang et al. 2005). For instance, our samples were measured at a pH of 2.2-3.15, which may affect our estimates as well as those from others who use this method of quantification.

\section{Origins of MAAs in different ice-covered environments}

Shinorine, porphyra-334 and U3 were present consistently throughout the water column and within most of the ice algae communities sampled (Fig. 5), suggesting their production within both environments. Porphyra-334 has been identified previously as the dominant MAA present in Antarctic ice algae communities (Karentz et al. 1991, Ryan et al. 2002), consistent with our samples collected under thick and medium snow cover. In contrast, samples collected beneath thin snow covers, and eventually melt ponds, contained shinorine as the dominant identified MAA. This observation suggests that shinorine production may be preferred for ice algae under greater light stress. Palythine and U1 were only detected in the water column and interface water under melt ponds, suggesting production was associated mainly with the water column environment (Fig. 5).
Of potential significance is that the structurally unidentified U2 was only observed in samples associated with melt ponds (e.g. surface melt ponds and bottom ice and interface water below melt ponds). It is important to note that U2 was never detected in bottom ice algae under snow-cover (i.e. prior to melt pond development) and white ice-cover, or in the water column underneath the ice at 2, 5, and $10 \mathrm{~m}$ depths. These observations suggest that U2 is uniquely associated with sea ice melt upon its exposure to higher UV radiation, which would agree well with its presence in the Baltic Sea ice upon experimental exposure to UV (Piiparinen et al. 2015). It can also be noted that U2 was only present when chl a concentrations were very low and light exposure was high. This suggests that it may be produced during times of high light stress, when organisms are attempting to acclimate or survive.

\section{Influence of light on production of UV absorbing compounds}

The development of melt ponds leads to greater transmission of UV radiation into and through the ice cover. Through direct exposure to incoming solar radiation and enhanced back scatter associated with the high albedo of surrounding sea ice, surface melt ponds are exposed to the highest light intensity (Fig. 2b; Perovich 2006, Ehn et al. 2011, Nicolaus et al. 2012). Few MAAs were encountered in melt ponds, but the occurrence of U2 presents the possibility of alternate screening compound(s). A comparison of MAA production in the bottom ice under thick and thin snow covers demonstrated a greater abundance and earlier presence of MAAs under the thin snow cover (Fig. 3d,g) where UV transmission (350$360 \mathrm{~nm}$ ) increased first and more rapidly after 4 June (Fig. 2b). This period corresponded to a rapid transition of thin snow to melt pond coverage, whereas the thick snow sites transitioned into a white ice cover. The ice-covered water column exhibited the lowest MAA nominal concentrations, which is to be expected as it would have received the lowest irradiance.

The highest nominal concentrations of MAAs within the bottom ice were observed immediately prior to melt pond formation and the termination of the bottom ice algal bloom when ice chl a concentrations were still high (Fig. $3 g, d$ ). Termination of the bloom was influenced by warming of the ice cover, increased transmitted irradiance, and most notably, rain events that caused sloughing off of the bottom ice protist community into the seawater (Campbell et 
al. 2014). It follows that the observed increase in MAAs was likely triggered by the higher UV transmission through the ice.

Bottom ice and interface water below melt ponds showed very high chl a-specific UV absorbing compound nominal concentrations in comparison to both the bottom ice prior to melt pond development and the water column throughout the study period (Fig. 3j-1). Surface melt ponds, where UV transmittance is the greatest, contained organisms with a higher capacity to absorb UV light relative to chl a concentrations. Chl a concentrations are likely reduced in melt pond organisms due to photoacclimation strategies in these high light regions, further contributing to high MAA:chl a ratios. The high UVabsorption capacity of organisms in surface melt ponds not only offers direct UV protection to melt pond organisms but may also contribute a layer of protection for underlying communities, reducing their need to produce these UV-absorbing compounds themselves.

\section{Taxonomic relationships}

A linear correlation analysis was performed between UVAC nominal concentrations and protist group abundances using data collected in June. The only UVAC that was present within more than one of the analyzed melt pond samples $(\mathrm{n}=4)$ was U2, and there was no significant correlation $(p>0.05)$ observed with any of the taxonomic protist groups identified (i.e. pennate diatoms, centric diatoms, flagellates and dinoflagellates). Within the water column samples analyzed ( $\mathrm{n}=7$ ), MAAs were not significantly correlated with the most prominent water column species, the pennate diatom F. arctica. A sig- nificant $(\mathrm{p}<0.05)$ positive correlation was only observed between MAA nominal concentration and the flagellate group. Therefore, we analyzed different flagellate taxa in water column samples (Table 1) and found a significant positive correlation between the total prasinophyte abundance with both shinorine (r $=0.77)$ and porphyra-334 $(\mathrm{r}=0.79)$, of which its most prominent taxa, Pyramimonas spp. of 6-10 $\mu \mathrm{m}$ in size, had a significant positive correlation with palythine $(r=0.79)$ and porphyra-334 $(r=0.83)$. Furthermore, the total prymnesiophyte abundance showed a positive correlation with porphyra-334 ( $\mathrm{r}=0.81)$. The most dominant prymnesiophyte taxa, Chrysochromulina spp. of 2-5 $\mathrm{mm}$ in size, also demonstrated significant correlations with shinorine $(\mathrm{r}=0.79)$ and porphyra-334 ( $\mathrm{r}=0.81$ ). Finally, the Prymnesiophyceae (2-5 $\mu \mathrm{m}$ in size) showed a negative correlation with $\mathrm{U} 3(\mathrm{r}=-0.86)$.

MAA production by the prymnesiophyte Phaeocystis pouchetii (Hariot) Lagerheim has been documented in Antarctic polar waters (Marchant et al. 1991) and in the Arctic near Svalbard (Ha et al. 2012); however, no significant correlation was seen between MAAs and $P$. pouchetii in the present study. The significant correlations of Chrysochromulina spp. and Pyramimonas spp. with specific UVACs provide evidence that these species could be producing the compounds (Table 1). Indeed, Mundy et al. (2011) observed a dominance of prymnesiophytes and prasinophytes in melt water samples as well as strong UV-particulate absorption properties that inferred the production of MAAs. However, we caution that experimental studies need to be performed with cultures to determine if these taxa are in fact MAA-producing algae. It is possible that the absorption peak observed in the melt water samples by Mundy et al. (2011) was not palythene as speculated

Table 1. Pearson's correlation coefficients of shinorine, palythine, porphyra-334, and 3 unknown UV-absorbing compounds (U1, U2 and U3) with total flagellate and flagellate group abundance in the water column samples from Allen Bay, Nunavut, Canada. Only those that are significant at $\mathrm{p}<0.05$ are shown

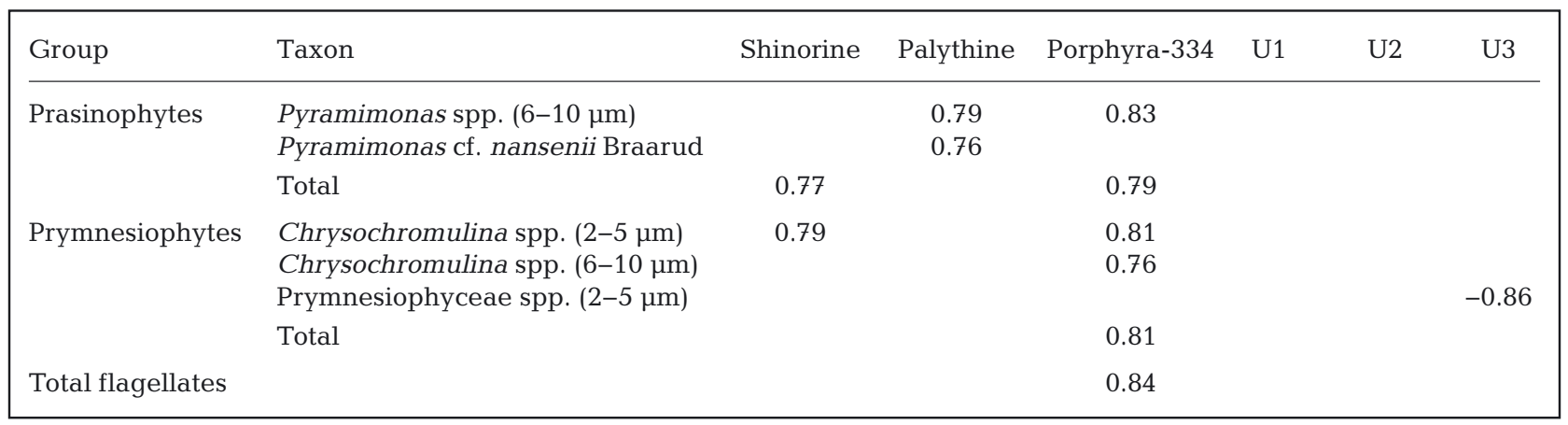


therein, since this MAA was not observed within the melt ponds throughout this study. The presence of U2 is the likely absorbing constituent (similar $\lambda_{\max }$ observed around $360 \mathrm{~nm}$ and absorption shoulder near 334 nm; Mundy et al. 2011), although we are unable to confirm it at this time.

These results confirm that Arctic sea ice-associated communities are capable of producing MAAs and other UVACs, which may play an important role in the Arctic marine ecosystem's response to changing light regimes from a warming climate and/or changing stratospheric ozone concentrations. Further studies are warranted to structurally identify the unknown UV-absorbing compounds (U1, U2, U3) and to uncover the role of MAAs and other photoprotectants in the Arctic marine ecosystem as a whole.

Acknowledgements. This research was funded by Natural Sciences and Engineering Research Council (NSERC) of Canada, ArcticNet (Network of Centres of Excellence of Canada), Canada Economic Development, the Northern Scientific Training Program of the Aboriginal Affairs and Northern Development Canada, Fonds de recherche du Québec-Nature et Technologies (FRQNT), the Canadian Museum of Nature, and the University of Manitoba. The Arctic-ICE camp was logistically supported by the Polar Continental Shelf Program (PCSP) of Natural Resources Canada. We thank Virginie Galindo and Robin Bénard for their assistance in the field, Sylvie Lessard for the enumeration and identification of protists, Tim Papakyriakou for providing air temperature data, and Marjolaine Blais for the logistics. We are indebted to Dr. Atsushi Matsuoka of Université Laval for providing shinorine, palythine and porphyra-334 standards to facilitate the structural identification. We thank 3 anonymous reviewers for their thorough and insightful comments on an earlier version of the manuscript. This is a contribution to the research programs of Arctic Science Partnership (ASP) and the Canada Excellence Research Chair (CERC) unit at the University of Manitoba.

\section{LITERATURE CITED}

Bowman JS, Rasmussen S, Blom N, Deming JW, Rysgaard S, Sicheritz-Ponten T (2012) Microbial community structure of Arctic multiyear sea ice and surface seawater by 454 sequencing of the 16S RNA gene. ISME J 6:11-20

Campbell K, Mundy CJ, Barber DG, Gosselin M (2014) Remote estimates of ice algae biomass and their response to environmental conditions during spring melt. Arctic 67:375-387

> Carignan MO, Cardozo KHM, Oliveira-Silva D, Colepicolo P, Carreto JI (2009) Palythine-threonine, a major novel mycosporine-like amino acid (MAA) isolated from the hermatypic coral Pocillopora capitata. J Photochem Photobiol B 94:191-200

> Carreto JI, Carignan MO (2011) Mycosporine-like amino acids: elevant secondary metabolites. Chemical and ecological aspects. Mar Drugs 9:387-446

Carreto JI, Carignan MO, Montoya NG (2001) Comparative studies on mycosporine-like amino acids, paralytic shell- fish toxins and pigment profiles of the toxic dinoflagellates Alexandrium tamarense, A. catenella and A. minutum. Mar Ecol Prog Ser 223:49-60

> Carreto JI, Carignan MO, Montoya NG (2005) A high-resolution reverse-phase liquid chromatography method for the analysis of mycosporine-like amino acids (MAAs) in marine organisms. Mar Biol 146:237-252

Carreto JI, Roy S, Whitehead K, Llewellyn CA, Carignan MO (2011) UV-absorbing 'pigments': mycosporine-like amino acids. In: Roy S, Llewellyn CA, Egeland ES, Johnsen G (eds) Phytoplankton pigments: characterisation, chemotaxonomy and applications in oceanography. Cambridge University Press, Cambridge, p 412-441

> Comiso JC, Parkinson CL, Gersten R, Stock L (2008) Accelerated decline in the Arctic sea ice cover. Geophys Res Lett 35:L01703, doi:10.1029/2007GL031972

Díez B, Bergman B, Pedrós-Alió C, Antó M, Snoeijs P (2012) High cyanobacterial nif $\mathrm{H}$ gene diversity in Arctic seawater and sea ice brine. Environ Microbiol Rep 4:360-366

> Dunlap WC, Yamamoto Y (1995) Small-molecule antioxidants in marine organisms: antioxidant activity of mycosporine-glycine. Comp Biochem Physiol B Biochem Mol Biol 112:105-114

Ehn JK, Mundy CJ, Barber DG, Hop H, Rossnagel A, Stewart J (2011) Impact of horizontal spreading on light propagation in melt pond covered seasonal sea ice in the Canadian Arctic. J Geophys Res Oceans 116:C00G02, doi:10.1029/2010JC006908

Eicken H, Krouse HR, Kadko D, Perovich DK (2002) Tracer studies of pathways and rates of meltwater transport through Arctic summer sea ice. J Geophys Res 107(C10): 8046, doi:10.1029/2000JC000583

Galindo V, Levasseur M, Mundy CJ, Gosselin M and others (2014) Biological and physical processes influencing sea ice, under-ice algae, and dimethylsulfoniopropionate during spring in the Canadian Arctic Archipelago. J Geophys Res 119:3746-3766

> Gao Q, Garcia-Pichel F (2011) Microbial ultraviolet sunscreens. Nat Rev Microbiol 9:791-802

> Garrison DL, Buck KR (1986) Organism losses during ice melting: a serious bias in sea ice community studies. Polar Biol 6:237-239

> Gröniger A, Sinha RP, Klish M, Häder DP (2000) Photoprotective compounds in cyanobacteria, phytoplankton and macroalgae - a database. J Photochem Photobiol B 58: 115-122

> Ha SY, Kim YN, Park MO, Kang SH, Kim HC, Shin KH (2012) Production of mycosporine-like amino acids of in situ phytoplankton community in Kongsfjorden, Svalbard, Arctic. J Photochem Photobiol B 114:1-14

> Holm-Hansen O, Lorenzen CJ, Holmes RW, Strickland JDH (1965) Fluorometric determination of chlorophyll. J Cons Int Explor Mer 30:3-15

Horner RA (2002) A taxonomic guide to some common marine phytoplankton. Biopress Limited, Bristol

Karentz D, McEuen FS, Land MC, Dunlap WC (1991) Survey of mycosporine-like amino-acid compounds in Antarctic marine organisms - potential protection from ultraviolet exposure. Mar Biol 108:157-166

> Karsten U, Sawall T, Hanelt D, Bischof K, Figueroa FL, FloresMoya A, Wiencke C (1998) An inventory of UV-absorbing mycosporine-like amino acids in macroalgae from polar to warm-temperate regions. Bot Mar 41:443-445

Landy J, Ehn J, Shields M, Barber D (2014) Surface and melt pond evolution on landfast first-year sea ice in the 
Canadian Arctic Archipelago. J Geophys Res Oceans 119:3054-3075

Llewellyn CA, White DA (2012) Distribution of mycosporinelike amino acids along a surface water meridional transect of the Atlantic. Microb Ecol 64:320-333

Lund JWG, Kipling C, Le Cren ED (1958) The inverted microscope method of estimating algal number and the statistical basis of estimations by counting. Hydrobiologia 11:143-170

Manney GL, Santee ML, Rex M, Livesey NJ and others (2011) Unprecedented Arctic ozone loss in 2011. Nature 478:469-475

Marchant HJ, Davidson AT, Kelly GJ (1991) UV-B protecting compounds in the marine alga Phaeocystis pouchetii from Antarctica. Mar Biol 109:391-395

- Maslanik J, Stroeve J, Fowler C, Emery W (2011) Distribution and trends in Arctic sea ice age through spring 2011. Geophys Res Lett 38:L13502, doi:10.1029/2011GL047735

Medlin LK, Hasle GR (1990) Some Nitzschia and related diatom species from fast ice samples in the Arctic and Antarctic. Polar Biol 10:451-479

Medlin LK, Priddle J (1990) Polar marine diatoms. British Antarctic Survey, Cambridge

Mundy CJ, Gosselin M, Ehn JK, Belzile C and others (2011) Characteristics of two distinct high-light acclimated algal communities during advanced stages of sea ice melt. Polar Biol 34:1869-1886

> Mundy CJ, Gosselin M, Gratton Y, Brown K and others (2014) Role of environmental factors on phytoplankton bloom initiation under landfast sea ice in Resolute Passage, Canada. Mar Ecol Prog Ser 497:39-49

> Nicolaus M, Katlein C, Maslanik J, Hendricks S (2012) Changes in Arctic sea ice result in increasing light transmittance and absorption. Geophys Res Lett 39:L24501, doi:10.1029/2012GL053738

> Oren A (1997) Mycosporine-like amino acids as osmotic solutes in a community of halophilic cyanobacteria. Geomicrobiol J 14:231-240

Parsons TR, Maita Y, Lalli CM (1984) A manual of chemical and biological methods for seawater analysis. Pergamon, Oxford

Perovich DK (2006) The interaction of ultraviolet light with Arctic sea ice during SHEBA. Ann Glaciol 44:47-52

Piiparinen J, Enberg S, Rintala JM, Sommaruga R, Majaneva M, Autio R, Vähätalo AV (2015) The contribution of mycosporine-like amino acids, chromophoric dissolved organic matter and particles to the UV protection of seaice organisms in the Baltic Sea. Photochem Photobiol Sci 14:1025-1038

Poulin M (1993) Craspedopleura (Bacillariophyta), a new diatom genus of arctic sea ice assemblages. Phycologia 32:223-233

> Poulin M, Cardinal A (1982a) Sea ice diatoms from Manitounuk Sound, southeastern Hudson Bay (Quebec, Canada). I. Family Naviculaceae. Can J Bot 60:1263-1278

Poulin M, Cardinal A (1982b) Sea ice diatoms from Manitounuk Sound, southeastern Hudson Bay (Quebec, Canada). II. Family Naviculaceae, genus Navicula. Can J Bot 60:2825-2845

Editorial responsibility: Ronald Kiene, Mobile, Alabama, USA
Poulin M, Cardinal A (1983) Sea ice diatoms from Manitounuk Sound, southeastern Hudson Bay (Quebec, Canada). III. Cymbellaceae, Entomoneidaceae, Gomphonemataceae, and Nitzschiaceae. Can J Bot 61:107-118

> Rex M, Harris NRP, von der Gathen P, Lehmann R and others (1997) Prolonged stratospheric ozone loss in the 1995-96 Arctic winter. Nature 389:835-838

> Ryan KG, McMinn A, Mitchell KA, Trenerry L (2002) Mycosporine-like amino acids in Antarctic sea ice algae, and their response to UVB radiation. Z Naturforsch $57 \mathrm{c}$ : 471-477

> Shick JM, Dunlap WC (2002) Mycosporine-like amino acids and related gadusols: biosynthesis, accumulation, and UV-protective functions in aquatic organisms. Annu Rev Physiol 64:223-262

Sinha RP, Klisch M, Gröniger A, Häder DP (2001) Responses of aquatic algae and cyanobacteria to solar UV-B. Plant Ecol 154:219-236

Sommaruga R, Chen YW, Liu ZW (2009) Multiple strategies of bloom-forming Microcystis to minimize damage by solar ultraviolet radiation in surface waters. Microb Ecol 57:667-674

> Spence E, Dunlap WC, Shick JM, Long PF (2012) Redundant pathways of sunscreen biosynthesis in a cyanobacterium. ChemBioChem 13:531-533

Suh HJ, Lee HW, Jung J (2003) Mycosporine glycine protects biological systems against photodynamic damage by quenching singlet oxygen with a high efficiency. Photochem Photobiol 78:109-113

Thomsen HA (1992) Plankton i de indre danske farvande. Havforskning fra Miljøstyrelsen, Vol 11. Scantryk, Copenhagen

Tomas CR (1997) Identifying marine phytoplankton. Academic Press, San Diego, CA

- Uusikivi J, Vahatalo AV, Granskog MA, Sommaruga R (2010) Contribution of mycosporine-like amino acids and colored dissolved and particulate matter to sea ice optical properties and ultraviolet attenuation. Limnol Oceanogr 55:703-713

Villafañe VE, Barbieri ES, Helbling EW (2004) Annual patterns of ultraviolet radiation effects on temperate marine phytoplankton off Patagonia, Argentina. J Plankton Res 26:167-174

Volkmann M, Gorbushina AA, Kedar L, Oren A (2006) Structure of euhalothece-362, a novel red-shifted mycosporine-like amino acid, from a halophilic cyanobacterium (Euhalothece sp.). FEMS Microbiol Lett 258: 50-54

von Quillfeldt $\mathrm{CH}$ (1997) Distribution of diatoms in the Northeast Water Polynya, Greenland. J Mar Syst 10: 211-240

Whitehead K, Karentz D, Hedges JI (2001) Mycosporine-like amino acids (MAAs) in phytoplankton, a herbivorous pteropod (Limacina helicina), and its pteropod predator (Clioneantarctica) in McMurdo Bay, Antarctica. Mar Biol 139:1013-1019

Zhang Z, Tashiro Y, Matsukawa S, Ogawa H (2005) Influence of $\mathrm{pH}$ and temperature on the ultraviolet-absorbing properties of porphyra-334. Fish Sci 71:1382-1384

Submitted: April 4, 2015; Accepted: October 30, 2015

Proofs received from author(s): November 25, 2015 